TAPROBANICA, ISSN 1800-427X. January, 2015. Vol. 07, No. 01: pp. 20-28, pls. 12-14.

(C) Research Center for Climate Change, University of Indonesia, Depok, Indonesia

\& Taprobanica Private Limited, Homagama, Sri Lanka

www.taprobanica.org

\title{
SPATIAL DISTRIBUTION AND HABITAT CORRELATES OF NILGIRI WOOD-PIGEON (Columba elphinstonii) IN NORTH WESTERN GHATS, INDIA
}

Section Editor: Varadharajan Gokula $\quad$ Submitted: 12 May 2014, Accepted: 30 November 2014

Pankaj Koparde $^{1}$, Monali Mhaskar ${ }^{2}$, Prachi Mhaske ${ }^{2}$ and Ankur Patwardhan ${ }^{2}$

${ }^{1}$ Sálim Ali Centre for Ornithology \& Natural History, Anaikatty, Coimbatore 641108, Tamil Nadu, India E-mail: pankajkoparde@gmail.com

${ }^{2}$ Department of Biodiversity, MES's Abasaheb Garware College, Karve road, Pune 411004, Maharashtra, India

\begin{abstract}
Nilgiri wood-pigeon (Columba elphinstonii) was surveyed in two forest types (open and closed) for spatial distribution and habitat correlates using belt transects across 94 localities in Sahyadri Tiger Reserve, India, during 2011-2013. Only closed forested localities showed presence of the species with maximum number of individuals sighted in evergreen forests. Poisson multiple regression analysis was conducted on species abundance data from 18 sites and seven variables. The species was found to be associated with high canopy cover and evergreen forests. Suitable habitat of the species was predicted using MaxEnt model. MaxEnt model showed high degree of suitable habitat in west Chandoli National Park and the corridor area of the tiger reserve. This paper provides fine scale distribution data and habitat correlates and discusses potential threats to the species in north Western Ghats and stresses the immediate need for conservation action in this area.
\end{abstract}

Keywords: avifauna, biogeography, conservation, distribution, ecology, endemic, habitat, threatened

\section{Introduction}

The distribution patterns of animals are mostly dependent on availability of suitable habitat (Coulon et al., 2004; Keyghobadi et al., 2005; Coulon et al., 2006). Due to discontinuity in suitable habitat, most species occur patchily across all or in parts of their distributional range (Koopman, 2007). Endemic species are restricted to specific areas with most being habitat specialists. Fragmented populations of endemic species suffer increased extinction probabilities mainly from demographic processes (Lande, 1988; Woodroffe \& Ginsberg, 1998). Without prior knowledge of habitat characteristics and effects of anthropogenic activities on endemic species' habitats and abundance, it is hard to identify hotspots for conservation and potential corridors and design appropriate conservation strategies. Western 
Ghats (WGs) of India and Sri Lanka, one of the global biodiversity hotspots (Myers et al., 2000), supports a number of endemic bird species, many of which are under threat from habitat degradation and loss (IUCN, 2014). Furthermore, their fine scale distribution and proximate factors affecting abundance are not well known. Nilgiri wood-pigeon (Columba elphinstonii Sykes, 1833) is one such endemic species of WGs in India (Jathar \& Rahmani, 2006; Grimmett et al., 2011; Rasmussen \& Anderton, 2012). The distributional range of the species lies within $8^{\circ}-19^{\circ} \mathrm{N}$ and $74^{\circ}-77^{\circ} \mathrm{E}$ (Birdlife International, 2012), but is restricted to evergreen and semi-evergreen forests within this range (Rasmussen \& Anderton, 2012). The species is known to be a mid and upper canopy dwelling frugivorous bird (Somasundaram \& Vijayan, 2010) that breeds March-July (Hume \& Oates, 1890; Blanford 1898; Baker et al., 1913; Ali \& Ripley, 1982; Rasmussen \& Anderton, 2012). It has been known to occupy a huge elevation gradient from $\sim 50 \mathrm{~m}$ to $2000 \mathrm{~m}$ a.s.1. (Rasmussen \& Anderton, 2012; Birdlife International, 2013). The species presence has been mentioned as 'erratic', varying in response to fruiting patterns (Baker et al., 1913; Somasundaram \& Vijayan, 2010; Rasmussen \& Anderton, 2012). The species has been listed under the vulnerable category according to the criteria C2aii of IUCN red-list of threatened species and has retained this status since 2000 (IUCN, 2014). It is under threat due to hunting for meat and habitat degradation primarily caused by plantations and deforestation (IUCN, 2014). Studies on the ecology and distribution of Nilgiri wood-pigeon are few, including those by Hume \& Oates (1890); Blanford (1898); Baker et al. (1913); Ali \& Ripley (1982); Subramanya (2005); Somasundaram \& Vijayan (2006, 2008, 2010) and Vijayan \& Gokula (2006). The northernmost limit of the species geographical distribution lies in the northwest of Maharashtra State (Birdlife International, 2012). The WGs of Maharashtra State are highly fragmented in terms of evergreen forest cover. There are no studies on locality specific distribution of the species and their drivers from such a highly fragmented forested landscape. There are only a few records of the species from various places in northern WGs (Gole, 1994a, b, 1998; Mahabal et al., 2011; Taware et al., 2012; Birdlife International, 2013).
In the recent IUCN assessment, decline in the species population in Maharashtra State has been attributed to loss of forest cover due to shifting cultivation and collection of timber for fuel and building (Birdlife International, 2012). This calls for studies on regional distribution of the species and factors affecting it. In this paper, we evaluate habitat preferences of the species, effects of various habitat variables on their abundance, and fine scale distribution of the species based on point location data generated through systematic surveys and habitat suitability modeling.

\section{Materials and Methods}

Study area: Sahyadri Tiger Reserve (STR), located between $16.5^{\circ}-18^{\circ} \mathrm{N}$ and $73.5^{\circ}-74^{\circ} \mathrm{E}$, is located in the Western Ghats of Maharashtra state, India (Fig. 1). The tiger reserve is spread across four districts: Ratnagiri, Kolhapur, Satara, and Sangli. STR comprises Koyna Wildlife Sanctuary (Koyna WLS), Chandoli National Park (Chandoli NP), and a corridor joining these two protected areas (PAs). STR is connected with patchy forested areas to Radhanagari WLS and Amba reserve forest (Amba RF) to its south and to forests of Mahabaleshwar to its north. The northern connection with forests of Mahabaleshwar and southern connection with Amba RF are under high pressure of tourism and habitat degradation. STR hosts a variety of landscape elements ranging from human modified landscape to virgin evergreen forests spread across an elevational range of 500-1100 m. A total of 94 localities (38 closed forests and 56 open forests) were sampled (Fig. 1 and appendix I) as a part of a multi-taxa survey project. Shape files of study area were obtained from DIVA-GIS spatial data portal (DIVA-GIS 2013).

Data collection: The study area was divided into grids of $5 \times 5 \mathrm{~km}\left(\sim 25 \mathrm{~km}^{2}\right)$ for easy allocation of transects. Two spatial belt transects (in open and closed forest), of $500 \times 50 \mathrm{~m}$, were laid in each grid. Most of the sites were sampled three times. Plant species composition was assessed on the same transects on which birds were surveyed. For this, a $500 \times 5 \mathrm{~m}$ belt transect was used. Based on plant species richness data obtained from these transects, evergreen species proportion was calculated. A Garmin Map 60CSx GPS was used to geo-reference transects, sighting locations of the species, and altitude in meters. Overhead canopy cover was calculated 
semi-quantitatively on a scale of $0-4,0$ being no canopy and 4 being 100\% canopy. This was done at 11 points across each transect and modal value was used for representing canopy cover. Transects with canopy cover more than 50\% were classified as closed forests. The sites were categorized into open forest and closed forest based on canopy cover. Open forest sites included dry-deciduous, scrubland, and scrubsavanna, and closed forest sites included moistdeciduous, semi-evergreen, and evergreen forest. Forest classification was based on Champion \& Seth (1968). Sampling was carried out during November 2011 - June 2013 at 07:00-12:00 hr. To calculate average distance to open forest and minimum distance to open forest, the transect area was digitized using line tool of Google Earth Pro (Google Inc. 2013) as shown in Figure 2. Transect start and end point and three additional points on the transect line were used. From each point, distances to open forest in four directions were measured. All the distances (four distances*five points) were averaged to get mean distance to open forest, and the minimum distance of all 20 distances was referred to as minimum distance to open forest. Cut stumps, non-timber forest products (NTFP) collection, cattle grazing, and invasive plant species were measured semi-quantitatively on a scale of $0-4$, 0 being absence and 4 being high degree of disturbance. NTFP collection was semiquantified by combining observations of flower, fruit and bark harvesting on transect, and information collected during informal discussions with villagers. The climate data were downloaded at 30' resolution from WorldClim database (Hijmans et al., 2005).

Data analysis: Although species presence was detected in 22 sites, data from only 18 sites were used for analysis for which first author had collected the data to reduce error due to multiple observers. Average number of individuals per locality was plotted against forest types, elevation classes, administrative areas and sampling seasons (winter and summer) separately. Months of November-February were considered as winter season and March-June as summer. Mean abundance per forest type was plotted against elevation classes. Poisson regression analysis was carried out on species abundance (count data) and habitat variables using R software v3.1.1. As the habitat variable data contained continuous as well as categorical variables, the regression analysis was run on continuous and categorical variables separately. Model 1 included species abundance and continuous habitat variables, and model 2 comprised of species abundance and categorical habitat variables. The regression models were tested for fit using goodness of fit test. The test checks whether the data fits the model by comparing residual deviance. If the residual deviance is small, then the test is not significant, suggesting that the data fit the model. A Spearman's rank correlation test was conducted on the variable dataset. To predict suitable habitat of the species across STR and to the south and north of STR, WorldClim database (Hijmans et al., 2005) was used along with MaxEnt v3.3.3e (Phillips et al., 2006; Phillips \& Dudik, 2008) and the output was presented in DIVA GIS v5.0 (Hijmans et al., 2004). For habitat suitability modeling, 19 bioclimatic variables and altitude were extracted from WorldClim database. A Spearman's rank correlation analysis was run on this dataset $(r>0.6$ or $r<-0.6$ and $p<0.05)$. In case of highly correlated variables, variables affecting species distribution were sorted based on data on species ecology. Three bioclimatic variables (Temperature seasonality-BIO4, precipitation seasonality-BIO15, precipitation of coldest quarter-BIO19) and altitude were considered for distribution modeling, based on the ecological data available for the species. The MaxEnt distribution was based on 10012 points (background and presence points) and crossvalidated on seven presence localities (test dataset). The quality of model was checked based on area under receiver operating characteristic curve (AUC) values. This curve essentially shows tradeoff between sensitivity and specificity. AUC is the probability of ranking a randomly chosen presence site above a randomly chosen absence site (Phillips \& Dudik, 2008). Models above 0.75 of AUC are generally considered potentially useful (Elith, 2002).

\section{Results}

Abundance of Nilgiri wood-pigeon varies with respect to forest types and seasons: the species was not present in any open forests. However, 22 out of 38 closed forest sites sampled had presence of the species. Out of the closed forest category, evergreen forest showed highest average abundance as compared to moistdeciduous and semi-evergreen forests which were equally populated (Fig. 3). In total, 71 individuals were recorded across all localities. 
The abundance per locality varied from 1-9 with a mean of 2. Maximum number of individuals was noted at Chandoli NP $(13 \pm 3)$ followed by Koyna WLS $(4 \pm 2)$ and the corridor $(3 \pm 1)$ (Fig. 4) (maximum \pm standard deviation). Elevation did not have considerable effect on abundance. However, moist-deciduous and semi-evergreen forest patches at $800-1000 \mathrm{~m}$ showed comparable abundance with evergreen forest patches (Fig. 5). The mean abundance across localities was found to be high during summer season (Fig. 6).

\section{Effect of Multiple Habitat Correlates on} Abundance of Nilgiri wood-pigeon: Out of continuous habitat variables, average distance to open forest and minimum distance to open forest were highly correlated $(\mathrm{r}=0.75793, \mathrm{P}=$ 0.0002 ). For model 1, average distance to open forest and average canopy cover were used and one independent variable namely minimum distance to open forest which was biologically less informative was excluded. Both the models fitted the data (goodness of fit test, $p=0.6$ and $p$ $=0.7$ respectively), but did not show any statistically significant effect of habitat variables on the species abundance.

Habitat Suitability Modelling: The AUC value for training and test dataset were 0.951 and 0.958 respectively. The model predicted that the suitable habitat of the species is clumped in western side of Chandoli NP, corridor and southern side of Koyna WLS (Fig. 7). Northern end of Koyna WLS was also predicted to be hosting suitable habitat of the species. In general, Chandoli NP was found to be the hotspot for Nilgiri wood-pigeon followed by North West of Koyna WLS. Corridor area showed high probability of suitable habitat. Precipitation seasonality (BIO15) showed maximum percentage permutation contribution (78\%) to the model followed by precipitation of coldest quarter (BIO19) (18.6\%) and temperature seasonality (BIO4) $(2 \%)$.

\section{Discussion}

Nilgiri wood-pigeon is a rare species in the forests of NWGs. During the survey we recorded only 71 individuals during 214 observations from 18 sites representing the low abundance of the species. We recorded the species from an additional four sites which were subsequently dropped from data analysis due to manual errors in counting caused by multiple observers. The species was exclusively found in closed forests, especially in evergreen forests. 22 out of 38 closed forest localities showed presence of the species, out of which 12 were evergreen forests, followed by moist-deciduous $(n=6)$ and semi-evergreen $(n=4)$. The mean abundance per locality in evergreen forests was high as compared to other forest types, clearly indicating that evergreen forests is likely preferred habitat of the species. This is also in accord with other previous studies (Blanford, 1898; Baker et al., 1913; Ali \& Ripley, 1982; Vijayan \& Gokula, 2006; Rasmussen \& Anderton, 2012). Evergreen forest patches across STR are relatively low in number, aggregated in Chandoli NP and sparsely distributed in Koyna WLS. This partially explains high abundance of the species in Chandoli NP. Going by administrative boundaries, corridor area of STR is relatively much smaller than the two PAs that it connects. However, it has comparable abundance with Koyna WLS. Although many studies have quoted presence of the species in evergreen and semi-evergreen forests, presence of the species in moist-deciduous forests was not earlier documented on a wide scale. We recorded the species from six moist-deciduous forested localities which fall in Chandoli NP. The presence of moist-deciduous forest patches in vicinity or in the middle of more or less continuous semi-evergreen and evergreen forest patches in the same area may have influenced the occurrence of the species in moist-deciduous forests. In addition, it was found that at high elevation (800-1000 m), moist-deciduous and semi-evergreen forest patches have comparable abundance with evergreen forest patches. Such moist-deciduous forest patches might be acting as local corridors or foraging sites for small scale movement. According to Rivera-Milan (1992), Columbiformes members might easily disperse to neighboring forests in the ecotone of dry and moist zones. Moreover, the species is known to be erratic in terms of distribution and has been known to follow fruiting patterns (Hume \& Oates, 1890; Blanford, 1898; Baker et al., 1913; Baker \& Inglis, 1930; Somasundaram \& Vijayan, 2010; Rasmussen \& Anderton 2012), which may have further affected detection. It is also possible that the presence of the species in moist-deciduous forests is under-estimated in this study, as the detection probability varies across space and time. Seasonality had considerable impact on species distribution and 
abundance (Fig. 6). Summer season showed increase in abundance relative to winter season. This also coincides with the breeding season of the species that has been known to be between March and July (Blanford, 1898; Hume \& Oates, 1890; Baker et al., 1913; Ali \& Ripley, 1982; Rasmussen \& Anderton, 2012). This seasonal variation might have skewed the abundance, as not all the sites were sampled in both the seasons. If we go by presence-absence data, evergreen forests can be said to be likely preferred forests by the species. However, the distribution of the species is seasonal and erratic as mentioned by Blanford (1898); Baker et al. (1913) and Baker \& Inglis (1930), and the possibility of moist-deciduous forests being preferred by the species cannot be ruled out based on abundance data. Given the available data on species ecology, we were expecting strong correlation between vegetation type, canopy cover and anthropogenic disturbance on the species abundance. The habitat variables collected did not show any statistically significant effect on species abundance. This might be due to less number of presence sites and very high variation in species abundance across localities, season and detection. Average canopy cover was weakly positively correlated with abundance. The association of the species with high canopy areas has been very well discussed previously by others. The species is known to be a canopy dwelling bird (Blanford, 1898; Hume \& Oates, 1913; Ali \& Ripley, 1982; Somasundaram \& Vijayan, 2010), using the canopy to roost during mid-day and night-times (Subramanya, 2005). NTFP collection showed moderate negative correlation with species abundance, implying that it may have a possible effect on abundance. Decorative flowers and edible fruits are one of the major parts of NTFP that villagers regularly collect. During the study we recorded many instances wherein Nilgiri wood-pigeons were observed to be feeding on fruits of Syzigium cumini (L.) which are readily harvested by villagers. However, NTFP involves a lot of other products which are not directly related to the feeding habits of the species. Moreover, while collecting data on NTFP collection, we had combined multiple variables such as fruit collection, flower collection and bark harvest in a single variable, losing independent data. This might have created an artifact in data analysis, and the relationship between NTFP collection and abundance might be incorrect. This was also reflected in the statistical non-significance of the analysis. Possible reason for the analysis to fail to resolve relationships is most probably low number of sites, count and categorical variable data. Having said this, continuous variables such as average distance to open forest and evergreen species proportion also did not show any relation with abundance. Although habitat patch size and species abundance relations are well established (see Dorp \& Opdom, 1987; Fahrig, 2003), our data failed to support it. This is mainly because of the highly fragmented forested landscape and that we dealt with single patch and not with the landscape matrix. Also, as Nilgiri wood-pigeon is a frugivorous species and known to follow fruiting, evergreen species proportion might not have detected variation in abundance, but abundance of fruits might detect it. Although not statistically significant, the dependence on high canopy cover can be underscored through the analysis.

In habitat suitability modeling, based on climate data, precipitation was found to be affecting species distribution largely as compared to other variables. Rainfall had been shown to have significant positive correlation with fruiting in forests of southern WGs (Murali \& Sukumar 1993; Kannan \& James, 1999; Sundarapandian et al., 2005). Nilgiri wood-pigeon is known to breed during March-July which coincides with the onset of monsoon justifying indirect effect of precipitation on species distribution. This pattern is in support with Somasundaram \& Vijayan (2010). The potential distribution of the species as predicted by MaxEnt model shows that the species suitable habitat is highly aggregated in western and central Chandoli NP, and corridor area of STR, which are also areas rich in less fragmented evergreen forest patches. A steep cliff at the western side of Chandoli NP makes these forest patches highly inaccessible to humans. Also due to legal protection, human approach to the central Chandoli NP has been lowered down. Nilgiri wood-pigeon has been recorded previously south of Chandoli NP in Amboli RF and Radhanagari WLS, and north of STR in Kirma valley in Satara and Bhimashankar WLS (Birdlife International, 2013). This supports the model prediction.

Nilgiri wood-pigeon is a globally vulnerable species and its IUCN status is unchanged since 2000. This calls for increased systematic conservation efforts to reduce immediate threats 
to the population as well as protection of potential habitats of the species. Our analysis shows that forests with high canopy cover, especially evergreen forests are crucial for survival of Nilgiri wood-pigeon in NWGs. In NWGs, forests are fast declining in size mostly due to anthropogenic activities (Birdlife International, 2012, 2013). With advent of developmental activities in buffer and corridor areas of STR, the closed forest patches in these areas are likely to get reduced in near future, causing severe loss of habitat of Nilgiri woodpigeon. Gole (1998) mentions MahabaleshwarMatheran-Chandoli-Radhanagari complex to be highly appropriate sites for conservation of the species and that these sites should receive effective protection. Chandoli NP and Koyna WLS, that still hold considerable population of Nilgiri wood-pigeon, have already been made a part of STR. The buffer areas of STR, especially the corridor area that joins both the PAs, is crucial in terms of effective conservation of the species across the landscape. In a recent study on Odonata fauna by Koparde et al. (2014), the corridor area was found to be hotspot for endemic odonates. In recent times, many species which were earlier known to be distributed south of Goa, have been found to be distributed to the northern tip of NWGs. This underscores importance of connectedness of forested landscape. With very few evergreen forest patches in the corridor area, it forms the only connection with northern forests of Western Ghats. This stressed the need for immediate action towards protecting the corridor area of STR. Further degradation of already fragmented forest patches within NWGs is highly likely to affect distribution of Nilgiri wood-pigeon, with high possibility of the species going locally extinct. This calls for locality specific conservation of this elusive species.

\section{Acknowledgements}

The study was supported under the ISRO-UoP initiative. We thank M.C. Uttam (Director, ISRO-UoP) for his encouragement; the Principal, Abasaheb Garware College, Pune, for his support; Maharashtra state forest department for giving us the permission to carry out the research; forest department officials, Shinde (Mandur range), Puranik (Koyna range), Patil (Bamnoli range) and Sali (Dhebewadi range), for supporting the research; Prajakta Pathare (BSI, Pune) for plant identification. We are grateful to all the researchers (Amruta Jogalekar,
Medhavi Tadwalkar, and Renuka Wagh) and students (Abhishek Narvekar, Apoorva Sahastrabuddhe, Priti Bangal, and Rakesh Deulkar) for field assistance. Finally, we thank Narayani Barve (Kansas State University), Nilesh Dahanukar (IISER, Pune, India), and Arundhati Das (Eco-informatics Lab, ATREE) for kind support and Michael Wasserman (Stedward's University, USA) for reviewing the manuscript.

\section{Literature cited}

Ali, S. and D. Ripley, 1982. Handbook of Birds of India and Pakistan, Volume III: Stone Curlews to Owls. Oxford University Press, New Delhi: 327.

Baker, E.C.S., H. Gronvold and G.E. Lodge, 1913. Indian Pigeons and Doves. Witherby and Co., London, UK: 342.

Baker, H.R. and C.M. Inglis, 1930. The Birds of Southern India, including Madras, Malabar, Travancore, Cochin, Coorg and Mysore. Superintendent, Government press, Madras, India: 504.

BirdLife International, 2012. Columba elphinstonii. The IUCN Red List of Threatened Species. Version 2014.2. <www.iucnredlist.org>. Downloaded on 24 June 2014.

BirdLife International, 2013. Species factsheet: Columba elphinstonii. Downloaded from <http://www.birdlife.org> on 24/06/2013.

Blanford, W. T. (Ed.), 1898. The Fauna of British India: Including Ceylon and Burma. Volume IV. Taylor \& Francis, London, UK: 532.

Champion, S.H. and S.K. Seth, 1968. A revised survey of the forest types of India. Government of India, New Delhi, India: 404.

Coulon A., J.F. Cosson, J.M. Angibault, B. Cargnelutti, M. Galan, N. Morellet, E. Petit, S. Aulagnier and A.J.M. Hewison, 2004. Landscape connectivity influences gene flow in a roe deer population inhabiting a fragmented landscape: an individual-based approach. Molecular Ecology, 13: 2841-2850.

Coulon A., G. Guillot, J.F. Cosson, J.M.A. Angibault, S. Aulagnier, B. Cargnelutti, M. Galan and A.J.M. Hewison, 2006. Genetic structure is influenced by landscape features: empirical evidence from a roe deer population. Molecular Ecology 15: 1669-1679. 
DIVA-GIS, 2013. DIVA-GIS spatial data by country retrieved from <http:// http://www.divagis.org/gdata on 21 February 2013.

Elith, J, 2000. Quantitative methods for modeling species habitat: comparative performance and an application to Australian plants. In: Quantitative methods for conservation biology. Springer, New York, United States of America: 39-58.

Fahrig, L, 2003. Effects of habitat fragmentation on biodiversity. Annual Review of Ecology, Evolution \& Systematics 34: 487-515.

Gole, P., 1994a. Birds of west coast. Newsletter of Birdwatchers, 34: 3-5.

Gole, P., 1994b. Birds of west coast. Newsletter of Birdwatchers, 34: 78-79.

Gole, P., 1998. Birds of Sahyadri. Journal of Ecological Society, 11: 5-28.

Google Inc., 2013. Google Earth Plus (version 6.0.0.1735) Beta. Retrieved from <http://www.google.com> on 5 June 2013.

Grimmett, R., C. Inskipp and T. Inskipp, 2011. Birds of the Indian Subcontinent. Oxford University Press, UK: 480.

Hijmans, R.J., L. Guarino, C. Bussink, P. Mathur, M. Cruz, I. Barrentes and E. Rojas, 2004. DIVAGIS. Version 5.0. A geographic information system for the analysis of species distribution data. Retrieved from <http://www.diva-gis.org> on 21 February 2013.

Hijmans, R.J., S. Cameron, J. Parra, P.G. Jones and A. Jarvis, 2005. WorldClim, version 1.3. University of California, Berkeley. Retrieved from <http://biogeo. berkeley. edu/worldclim/worldclim. html> on 21 February 2013.

Hume, A.O. and E.W. Oates, 1890. The Nests and Eggs of Indian Birds. Volume II. R.H. Porter, London, United Kingdom: 446.

IUCN 2014. IUCN Red List of Threatened Species. Version 2012.2. Retrieved from <http://www.iucnredlist.org/> on 15 June 2013.

Jathar, G.A. and A.R. Rahmani, 2006. Endemic birds of India. Buceros, 11: 5-46.
Kannan, R. and D.A. James, 1999. Fruiting phenology and the conservation of the Great Pied Hornbill (Bucerors bicornis) in the Western Ghats of Southern India. Biotropica, 31: 167-177.

Keyghobadi, N., J.E.N.S. Roland, and C. Strobeck, 2005. Genetic differentiation and gene flow among populations of the alpine butterfly, Parnassius smintheus, vary with landscape connectivity. Molecular Ecology, 14: 1897-1909.

Koopman, M.E., G.D. Hayward, and D.B. McDonald, 2007. High connectivity and minimal genetic structure among north American Boreal Owl (Aegolius funereus) populations, regardless of habitat matrix. The Auk, 124: 690-704.

Koparde, P., P. Mhaske, and A. Patwardhan, 2014. New records of dragonflies and damselflies (insecta: odonata) from the Western Ghats of Maharashtra, India. Journal of Threatened taxa, 6: 5744-5754.

Lande, R., 1988. Genetics and demography in biological conservation. Science, 241: 1455-1460.

Mahabal, A., S. Pande, P. Pandit and A, Ponkshe, 2011. Fauna of Maharashtra - State Fauna Series (Part 1), Zoological Survey of India. India: 147188.

Murali, K.S. and R. Sukumar, 1993. Reproductive phenology of a tropical dry forest in Mudumalai, Southern India. Journal of Ecology, 82: 759-767.

Myers, N., R.A. Mittermeier, C.G. Mittermeier, G.A. Da Fonseca and J. Kent, 2000. Biodiversity hotspots for conservation priorities. Nature, 6772: 853-858.

Phillips, S.J. and M. Dudík, 2008. Modeling of species distributions with Maxent: new extensions and a comprehensive evaluation. Ecography, 31: 161-175.

Phillips, S.J., R.P. Anderson and R.E. Schapire, 2006. Maximum entropy modeling of species geographic distributions. Ecological modeling 190: 231-259.

Rassmusen, P.C. and J.C. Anderton, 2012. Birds of South Asia. The Ripley Guide. Volumes I and II. Smithsonian Institution and Lynx Editions, Washington, D.C, USA: 1072. 
Rivera-Milan, F.F., 1992. Distribution and relative abundance patterns of Columbids in Puerto Rico. Condor, 94: 224-238.

Somasundaram, S. and L. Vijayan, 2006. Impact of habitat alteration on the globally threatened Nilgiri wood pigeon in the Western Ghats, India. Journal of Ornithology, 147: 255-265.

Somasundaram, S. and L. Vijayan, 2008. Foraging behavior and guild structure of birds in montane wet temperate forest of the Palani Hills, South India. Podoces, 3: 79-91.

Somasundaram, S. and Vijayan L., 2010. Foraging ecology of the globally threatened Nilgiri wood pigeon (Columba elphinstonii) in the Western Ghats, India. Chinese Birds, 1: 9-21.

Subramanya, S., 2005. Nesting of Nilgiri wood pigeon Columba elphinstonii at Nandi Hills, Karnataka, India. Indian Birds, 1: 36-37.

Sundarapandian, S.M., S. Chanderasekaran and P.S. Swamy, 2005. Phenological behaviour of selected tree species in tropical forests at Kodayar in the Western Ghats, Tamil Nadu, India. Current Science, 88: 805-810.

Taware, S.S., V.M, Lagade, D.V. Muley and K.B. Koli, 2012. Checklist of birds at Bhatye estuary and adjacent areas, Maharashtra. Zoo's Print, 27: 22-26.

van Dorp, D., P.F.M. Opdam, 1987. Effects of patch size, isolation and regional abundance on forest bird communities. Landscape Ecology, 1: 59-73.

Vijayan, L. and V. Gokula, 2006. Human impacts on forest bird communities in the Western Ghats, India. Acta Zoologica Sinica, 52: 692-696.

Woodroffe, R. and J.R. Ginsberg, 1998. Edge effects and the extinction of populations inside protected areas. Science, 5372: 2126-2128. 
Appendix 1: Details of survey localities where Nilgiri wood-pigeon were sighted. (SEVG, Semi-evergreen forest; EVG, Evergreen forest; MDCD, Moist-deciduous forest; SCRUB, Scrub-land; LTP, Lateritic plateau; X, Presence of the species).

\begin{tabular}{|c|c|c|c|c|c|c|}
\hline Locality & Latitude & Longitude & $\begin{array}{c}\text { Elevation } \\
(\mathrm{m})\end{array}$ & Strata & $\begin{array}{c}\text { Forest } \\
\text { Type }\end{array}$ & Presence \\
\hline Bahe & $17^{\circ} 18^{\prime} 32.79^{\prime \prime}$ & $73^{\circ} 48^{\prime} 14.58^{\prime \prime}$ & 924 & Closed & SEVG & $X$ \\
\hline Valvan & $17^{\circ} 44^{\prime} 09.24^{\prime \prime}$ & $73^{\circ} 34^{\prime} 58.25^{\prime \prime}$ & 695 & Closed & SEVG & $\mathrm{X}$ \\
\hline Pali & $17^{\circ} 36^{\prime} 00.75^{\prime \prime}$ & $73^{\circ} 43^{\prime} 50.55^{\prime \prime}$ & 714 & Closed & EVG & $X$ \\
\hline Maldev & $17^{\circ} 38^{\prime} 16.91^{\prime \prime}$ & $73^{\circ} 43^{\prime} 16.82^{\prime \prime}$ & 687 & Closed & EVG & $X$ \\
\hline Kolne & $17^{\circ} 19^{\prime} 32.23^{\prime \prime}$ & $73^{\circ} 43^{\prime} 09.76^{\prime \prime}$ & 742 & Closed & EVG & $\mathrm{X}$ \\
\hline Patharpunj & $17^{\circ} 18^{\prime} 37.58^{\prime \prime}$ & $73^{\circ} 41^{\prime} 31.48^{\prime \prime}$ & 922 & Closed & EVG & $\mathrm{X}$ \\
\hline Atoli & $17^{\circ} 18^{\prime} 18.93 "$ & $73^{\circ} 46^{\prime} 5.087^{\prime \prime}$ & 980 & Closed & EVG & $\mathrm{X}$ \\
\hline Male & $17^{\circ} 17^{\prime} 1.283^{\prime \prime}$ & $73^{\circ} 42^{\prime} 15.80^{\prime \prime}$ & 831 & Closed & EVG & $\mathrm{X}$ \\
\hline Rundiv & $17^{\circ} 14^{\prime} 38.29^{\prime \prime}$ & $73^{\circ} 43^{\prime} 01.81^{\prime \prime}$ & 786 & Closed & EVG & $\mathrm{X}$ \\
\hline Vetti & $17^{\circ} 14^{\prime} 45.85^{\prime \prime}$ & $73^{\circ} 45^{\prime} 35.42^{\prime \prime}$ & 1012 & Closed & EVG & $X$ \\
\hline Siddheshwar & $17^{\circ} 11^{\prime} 23.24^{\prime \prime}$ & $73^{\circ} 43^{\prime} 00.51^{\prime \prime}$ & 800 & Closed & EVG & $X$ \\
\hline Chandel & $17^{\circ} 09^{\prime} 46.58^{\prime \prime}$ & $73^{\circ} 42^{\prime} 36.14^{\prime \prime}$ & 854 & Closed & EVG & $\mathrm{X}$ \\
\hline Jholambi & $17^{\circ} 11^{\prime} 12.01 "$ & $73^{\circ} 50^{\prime} 29.47^{\prime \prime}$ & 946 & Closed & MDCD & $X$ \\
\hline Navja & $17^{\circ} 26^{\prime} 12.98^{\prime \prime}$ & $73^{\circ} 43^{\prime} 09.04^{\prime \prime}$ & 954 & Closed & EVG & $\mathrm{X}$ \\
\hline Kolhapur Nivle & $17^{\circ} 05^{\prime} 39.08^{\prime \prime}$ & $73^{\circ} 48^{\prime} 04.10^{\prime \prime}$ & 916 & Closed & MDCD & $X$ \\
\hline Kasani & $17^{\circ} 10^{\prime} 42.85^{\prime \prime}$ & $73^{\circ} 54^{\prime} 29.19^{\prime \prime}$ & 687 & Closed & MDCD & $\mathrm{X}$ \\
\hline Kalemba & $17^{\circ} 3^{\prime} 59.364^{\prime \prime}$ & $73^{\circ} 48^{\prime} 31.42^{\prime \prime}$ & 876 & Closed & EVG & $X$ \\
\hline Udgiri & $17^{\circ} 02^{\prime} 47.76^{\prime \prime}$ & $73^{\circ} 51^{\prime} 11.05^{\prime \prime}$ & 850 & Closed & SEVG & $\mathrm{X}$ \\
\hline Vankoli RF & $16^{\circ} 59^{\prime} 42.32^{\prime \prime}$ & $73^{\circ} 50^{\prime} 13.59^{\prime \prime}$ & 844 & Closed & SEVG & $\mathrm{X}$ \\
\hline Paneri & $17^{\circ} 13^{\prime} 27.19^{\prime \prime}$ & $73^{\circ} 49^{\prime} 50.12^{\prime \prime}$ & 1060 & Closed & MDCD & $\mathrm{X}$ \\
\hline East Chandel & $17^{\circ} 09^{\prime} 14.83^{\prime \prime}$ & $73^{\circ} 45^{\prime} 59.72^{\prime \prime}$ & 844 & Closed & MDCD & $X$ \\
\hline Golivane & $17^{\circ} 02^{\prime} 26.84^{\prime \prime}$ & $73^{\circ} 51^{\prime} 11.62^{\prime \prime}$ & 829 & Closed & MDCD & $\mathrm{X}$ \\
\hline Aloli & $17^{\circ} 12^{\prime} 09.17^{\prime \prime}$ & $73^{\circ} 46^{\prime} 15.81^{\prime \prime}$ & 654 & Closed & SEVG & \\
\hline Ambeshwar & $16^{\circ} 58^{\prime} 28.45^{\prime \prime}$ & $73^{\circ} 48^{\prime} 04.39^{\prime \prime}$ & 611 & Closed & SEVG & \\
\hline Avasari & $17^{\circ} 29^{\prime} 03.94^{\prime \prime}$ & $73^{\circ} 46^{\prime} 29.53^{\prime \prime}$ & 713 & Closed & MDCD & \\
\hline Dhopeshwar & $16^{\circ} 55^{\prime} 46.48^{\prime \prime}$ & $73^{\circ} 50^{\prime} 54.52^{\prime \prime}$ & 803 & Closed & SEVG & \\
\hline East Maldev & $17^{\circ} 38^{\prime} 01.68^{\prime \prime}$ & $73^{\circ} 45^{\prime} 00.54^{\prime \prime}$ & 664 & Closed & MDCD & \\
\hline Kondawle & $17^{\circ} 21^{\prime} 06.62^{\prime \prime}$ & $73^{\circ} 43^{\prime} 01.77^{\prime \prime}$ & 910 & Closed & SEVG & \\
\hline Kumbharli & $17^{\circ} 22^{\prime} 47.13^{\prime \prime}$ & $73^{\circ} 40^{\prime} 58.72^{\prime \prime}$ & 712 & Closed & EVG & \\
\hline Kusawade & $17^{\circ} 31^{\prime} 23.30^{\prime \prime}$ & $73^{\circ} 46^{\prime} 23.41^{\prime \prime}$ & 719 & Closed & MDCD & \\
\hline Manoli & $16^{\circ} 56^{\prime} 09.70^{\prime \prime}$ & $73^{\circ} 47^{\prime} 35.23^{\prime \prime}$ & 822 & Closed & EVG & \\
\hline Metindoli & $17^{\circ} 40^{\prime} 36.55^{\prime \prime}$ & $73^{\circ} 43^{\prime} 25.31^{\prime \prime}$ & 683 & Closed & SEVG & \\
\hline Nechal & $17^{\circ} 21^{\prime} 45.64^{\prime \prime}$ & $73^{\circ} 41^{\prime} 23.53^{\prime \prime}$ & 644 & Closed & SEVG & \\
\hline Takale & $17^{\circ} 12^{\prime} 12.31^{\prime \prime}$ & $73^{\circ} 48^{\prime} 27.79^{\prime \prime}$ & 933 & Closed & MDCD & \\
\hline Velhe Khore & $17^{\circ} 33^{\prime} 17.42^{\prime \prime}$ & $73^{\circ} 45^{\prime} 59.18^{\prime \prime}$ & 859 & Closed & MDCD & \\
\hline West Avasari & $17^{\circ} 29^{\prime} 01.31^{\prime \prime}$ & $73^{\circ} 44^{\prime} 14.67^{\prime \prime}$ & 774 & Closed & MDCD & \\
\hline West Kusawade & $17^{\circ} 30^{\prime} 30.56^{\prime \prime}$ & $73^{\circ} 43^{\prime} 13.54^{\prime \prime}$ & 686 & Closed & MDCD & \\
\hline West Velhe & $17^{\circ} 34^{\prime} 41.98^{\prime \prime}$ & $73^{\circ} 44^{\prime} 11.79^{\prime \prime}$ & 670 & Closed & MDCD & \\
\hline
\end{tabular}




\section{PLATE 12}

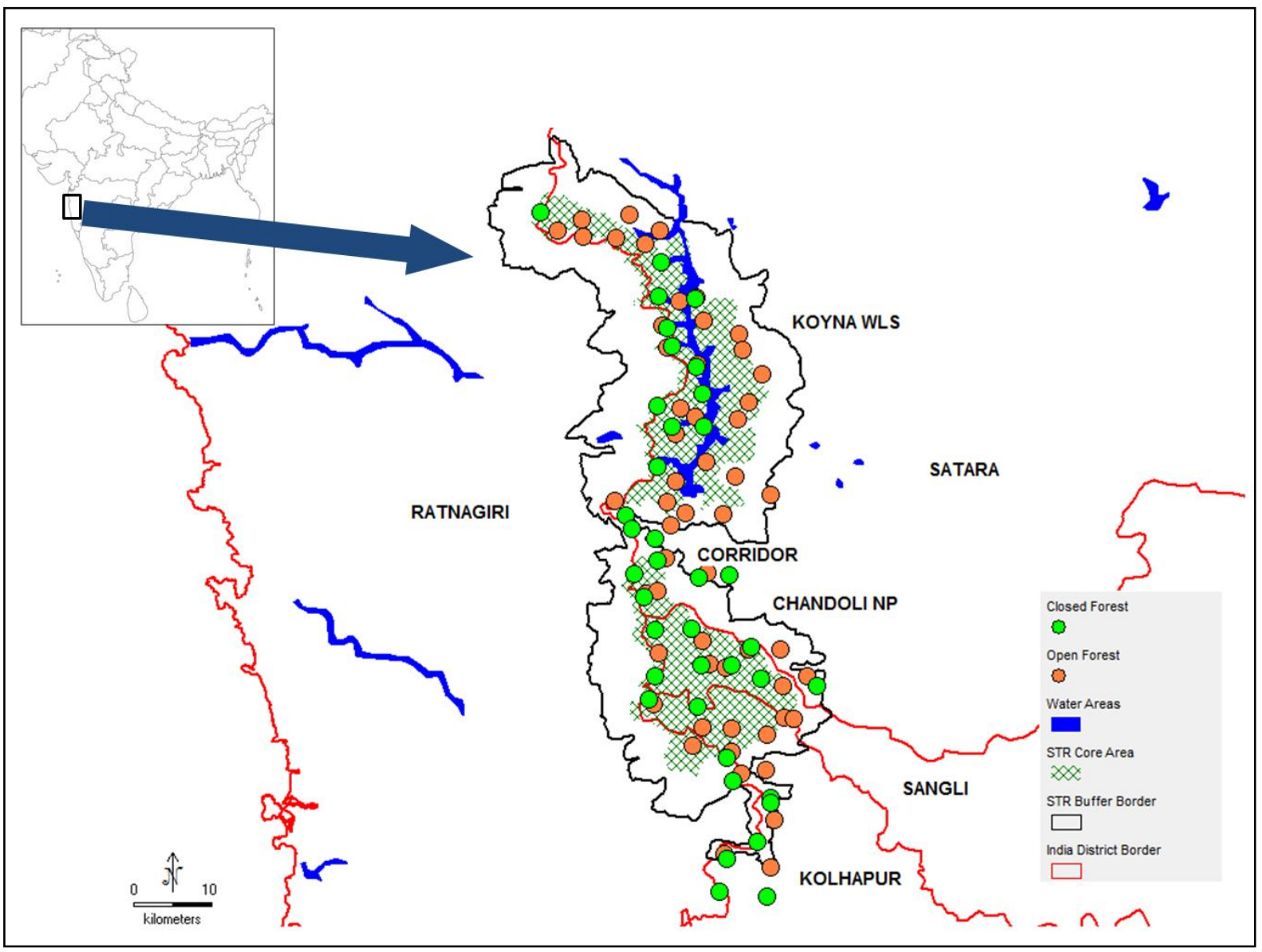

Figure 1: Map of sampling localities in STR, Maharashtra, India.

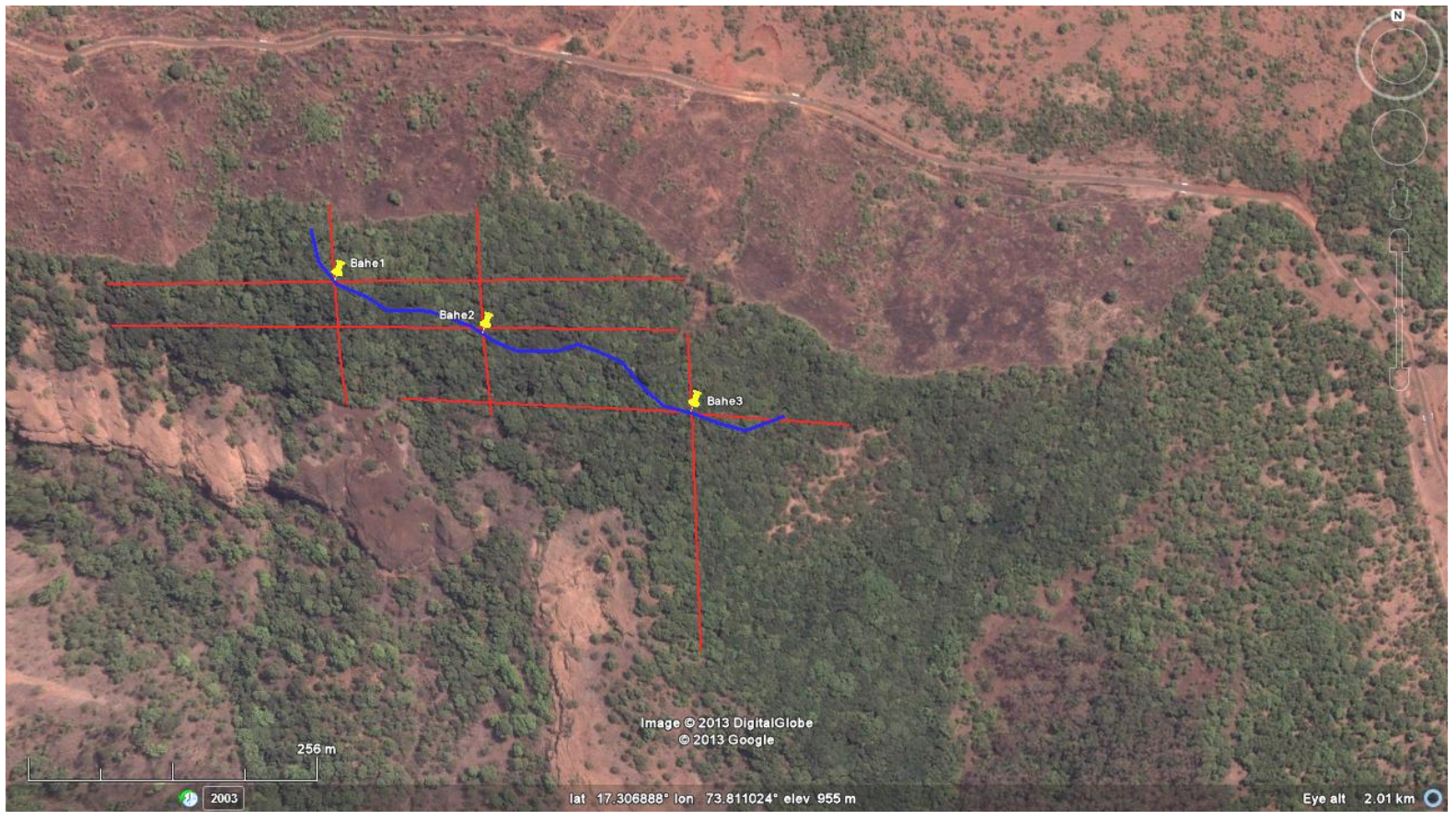

Figure 2: Calculation of average distance to open forest and minimum distance to open forest from five points on transect. 


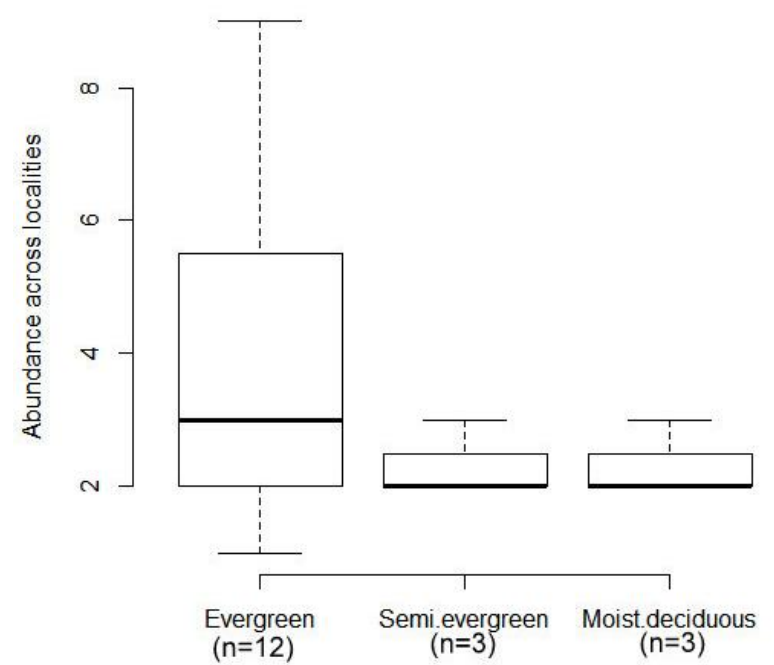

Figure 3: Abundance across forest types.

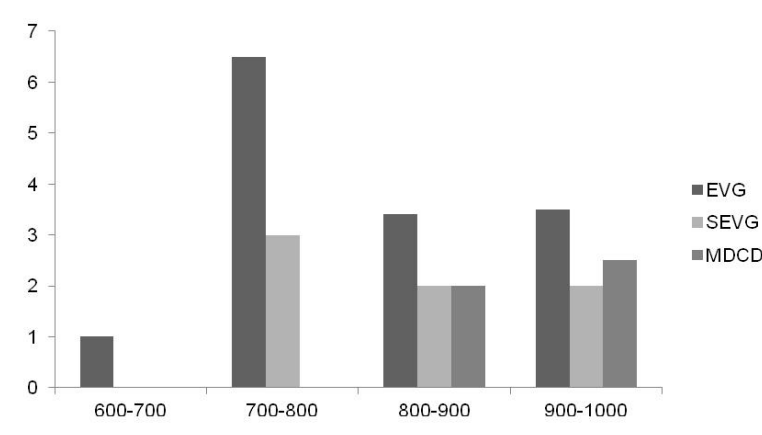

Figure 5: Abundance across forest types and elevational bands. Elevational bands are in meters.

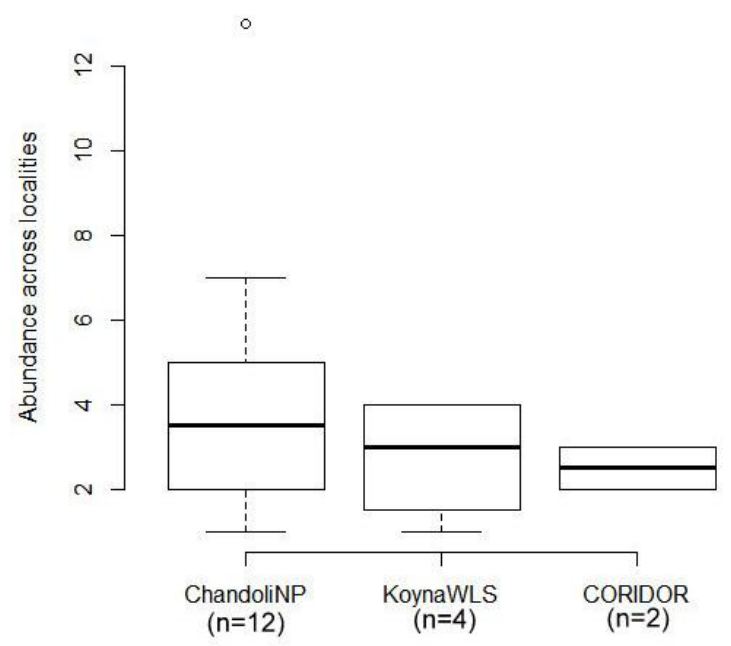

Figure 4: Abundance across administrative areas of STR.

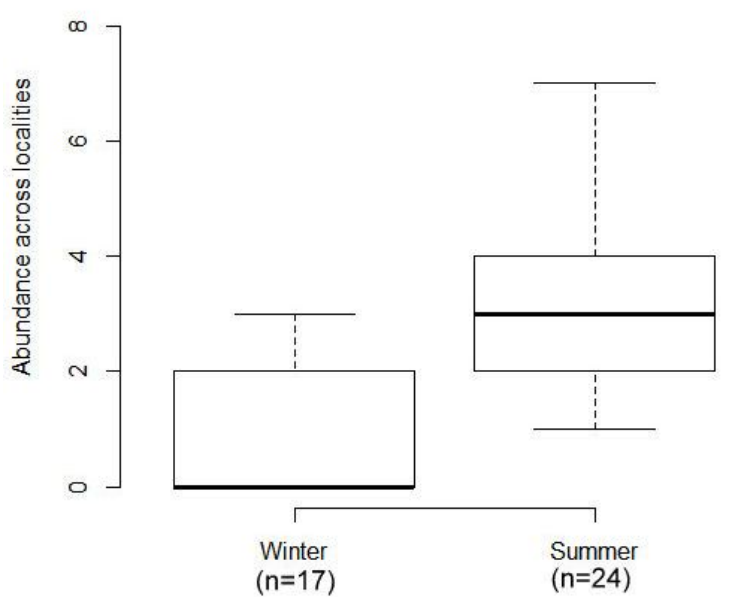

Figure 6: Abundance across seasons. 


\section{PLATE 14}

\section{Legend}

- Presence Locations

$\square$ STR_Core_Border

$\square$ STR_Buffer_Border

NWP_MaxEnt_Distribution

0.000017

0.067713

0.135408

0.203104

0.270800

0.338496

0.406192

0.473888

0.541584

0.609280

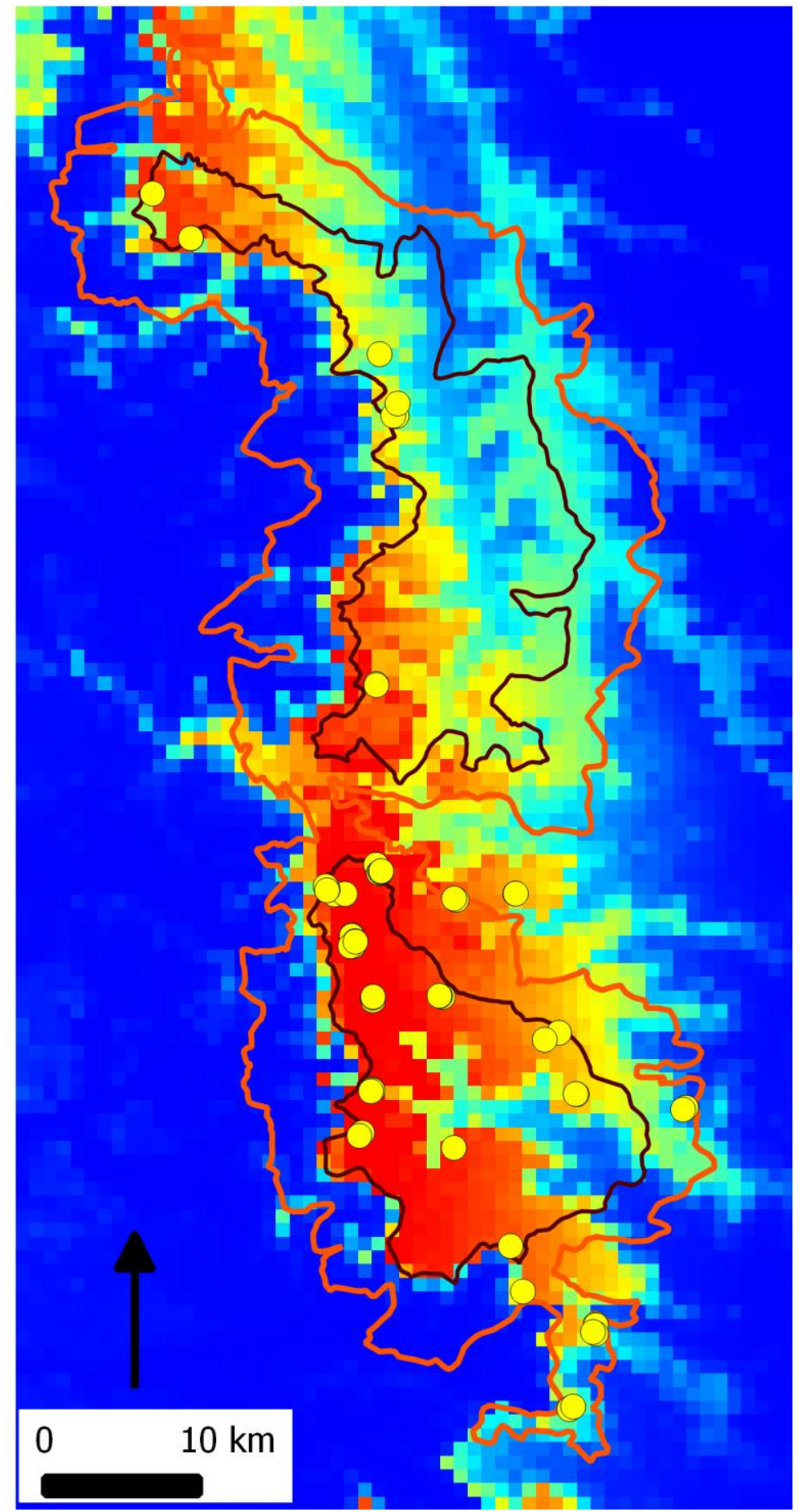

Figure 7: MaxEnt prediction of distribution of C. elphinstonii across STR. The numbers represent probability of suitable habitat that ranges between 0-1 (low to high). 